\title{
Seismicity of Western Jordan
}

\author{
by \\ Robert L. Kovach 1 \\ Gordon E. Andreasen ${ }^{2}$ \\ Mark E. Gettings 3 \\ John H. Healy
}

4 November 1986

${ }^{1}$ Department of Geophysics, Stanford University and U.S. Geological Survey, Menlo Park, California.

${ }^{2}$ U.S. Agency for International Development, Amman, Jordan.

${ }^{3}$ U.S. Geological Survey, Reston, Virginia.

${ }^{4}$ U.S. Geological Survey, Menlo Park, California.

\section{U.S. Geological Survey \\ Open File Report 86-561}

This report is preliminary and has not been edited or reviewed for conformity with Geological Survey Standards and nomenclature 


\section{Table of Contents}

1. Introduction

2. Historical Seismicity

3. Seismic Stations and Future Expansion of Jordan Network

4. Crustal Structure of Western Jordan

5. Epicentral Locations and Overall Seismicity Pattern

6. Tectonic Framework and Focal Plane Solutions

7. Acknowledgments

8. References 


\section{List of Figures}

Figure 1-1: Geographic Location of the Dead Sea Rift Zone. 2

Figure 2-1: Historical Seismicity of Jordan and Vicinity Compiled 3 from Various Sources.

Figure 3-1: Location of Selsmograph Stations in Jordan and 5 Adjacent Areas and Future Stations of the Jordan Network.

Figure 4-1: Index Map Showing Location of Seismic Refraction 8 Profiies in the Vicinity of the Dead Sea Rift Zone.

Figure 4-2: interpreted Crustal Veiocity Section for North-South Profile in Jordan. Shot-Point 2 is Near Amman (El-Isa et al, 1986).

Figure 4-3: Adopted Crustal Velocity Model for Western Jordan

Compared with Velocity Model Previously Used (Kovach et al, 1986).

Figure 5-1: Epicentral Map of Western Jordan for the Year 1985.

Figure 6-1: A Model for the Overall Structure of the Dead Sea Rift 17 (Freund, 1965).

FIgure 6-2: Model for the Formation of Rhomb Grabens or Pull18 Apart Basins Along the Northern Segment of the Dead Sea Rift (Freund and Garfunkel, 1976).

Figure 6-3: Cartoon showing the Presumed Development of the Dead Sea Basin (Freund and Garfunkel, 1976).

Figure 6-4: Focal Plane Solutions for Some Earthquakes Near the Dead Sea Rift Zone. 


\section{List of Tables}

Table 3-1: Seismic Stations in Jordan and Vicinity, Geographical 6 Locations and Elevations.

Table 5-1: Comparison of Hypocenter Locations Using Old and 12 New Crustal Velocity Models.

Table 5-2: Trial Station Delays for Some Jordan Seismic 13 Stations.

Table 5-3: Comparison of Hypocenter Locations Using HYPO71 With and Without Station Corrections and LME83 Without Station Corrections. 


\section{Introduction}

The Dead Sea Rift zone extends from the northern end of the Red Sea for a distance in excess of $1000 \mathrm{~km}$. Along a great portion of this fault zone there are present several linear topographic fault controlled depressions. Within the purview of plate tectonics, the Dead Sea Rift is a transform plate boundary connecting the Red Sea, where crustal spreading is occurring, northward to a zone of plate convergence. The Arabian plate lies to the east of the rift whereas on the west several smaller plates, the largest of which is the Sinai microplate, form a part of the larger African plate (Figure 1-1).

In the latter part of 1983 the Hashemite Kingdom of Jordan installed a seismic network of 8 stations, ultimately to be expanded to 32 stations, including some three-component stations, with the objective of discerning the overall pattern of microearthquake activity in Jordan (Kovach et al, 1986). The goal is to understand the tectonic activity in this region and thus provide a firm data base for estimating earthquake hazard and risk.

\section{Historical Seismicity}

A large amount of literature has been written concerning the historical seismic record of the Middle East. In general, there are three main sources of data: (1) earthquake listings or catalogs; (2) descriptions of specific events and (3) inferences from archaeological excavations.

Earthquake listings have been presented by Alsinawi and Ghalib (1975), Ambrayseys (1961, 1962), Ambrayseys and Melville (1982), Amiran (1950, 1951), Arieh (1967, 1985), BenMenahem (1979), Perrey (1849), Poirer and Taher (1980), Poirer et al, (1980), Sieberg (1932a), Sprenger (1843) and Willis (1928).

Specific seismic events have been analyzed or their effects described by Arieh et al, (1977, 1982), Ben-Menahem et al, (1977), Blanckenhom (1905, 1925, 1927), El-Isa et al, (1984), El-Isa and Mustafa (1986), Sieberg (1932b), Tristram (1865, 1874), Vered and Striem (1977) and Watson (1895). Archaeological evidence for earthquake events in the period from 1050 B.C. to 1070 A.D. (Timna area and at Ram, $40 \mathrm{~km}$ east of Aqaba, Figure 2-1) can be found in AviYonah (1975-1976).

Figure 2-1 is a compilation of earthquake epicenters for Jordan and its near vicinity from 2150 B.C. to 1981 for events of magnitude 4.1 or greater. The first major earthquake to be recorded instrumentally was the July $11,1927, \mathrm{M}_{\mathrm{L}}=6.25$ event near Jericho $\left(32.0^{\circ} \mathrm{N}, 35.5^{\circ} \mathrm{E}\right)$. Magnitudes of the earlier events have been inferred from : rica eismic intensity-magnitude 
Figure 1-1: Geographic Location of the Dead Sea Rift Zone.

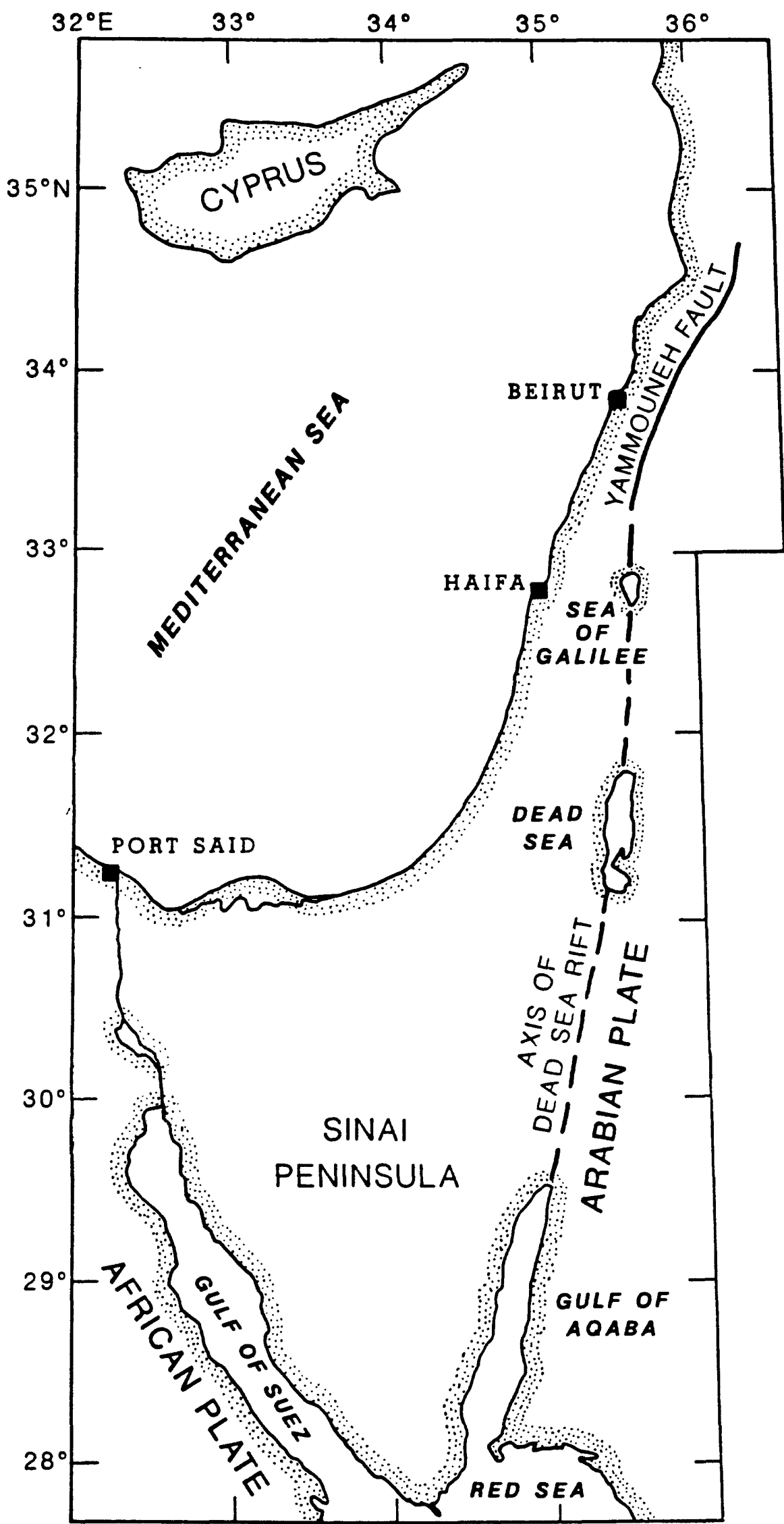


Figure 2-1: Historical Seismicity of Jordan and Vicinity Compiled from Various Sources.

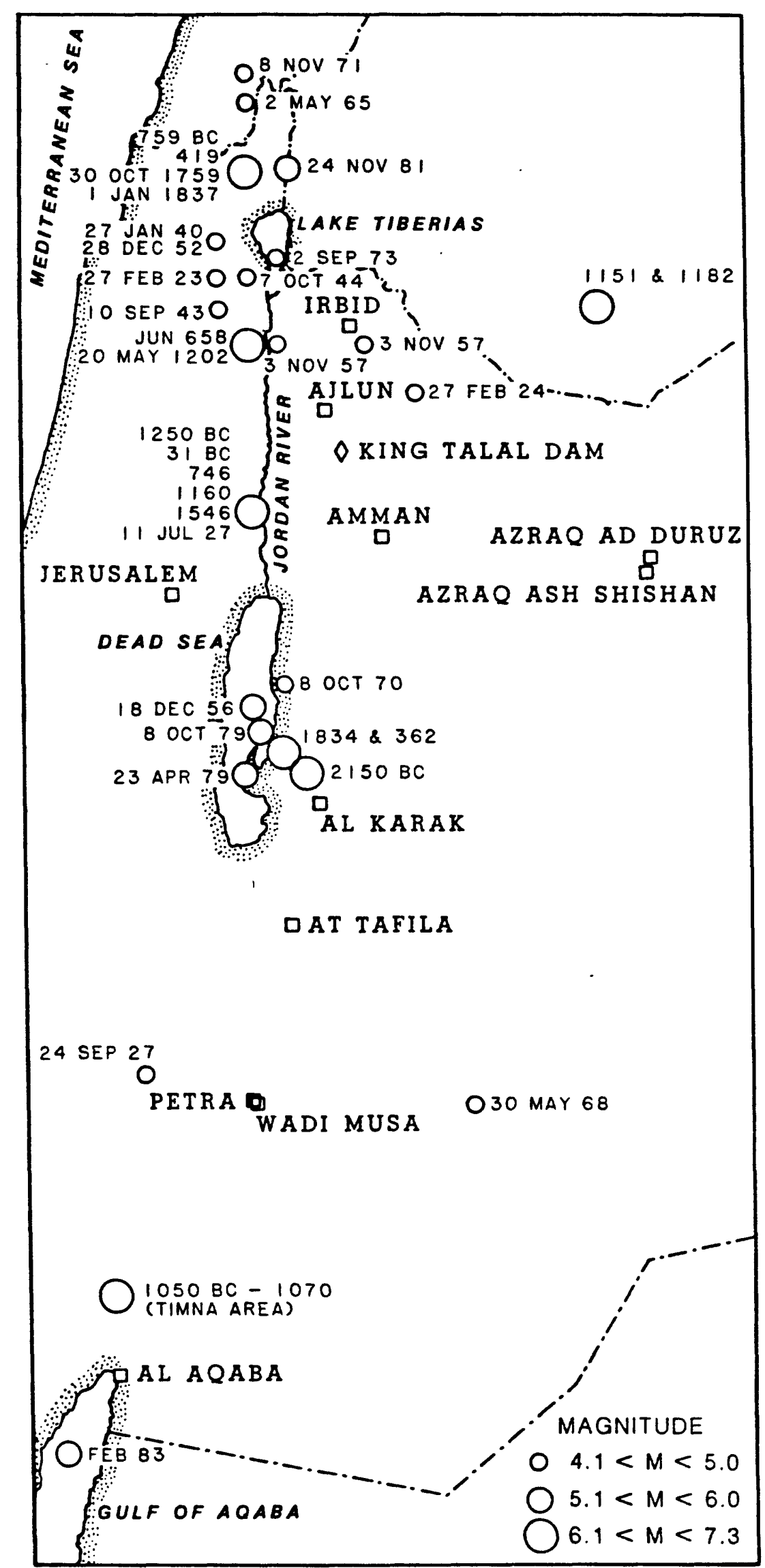


relations which have been calibrated for Middle East earthquakes (Ben-Menahem, 1979). Certainly for the very ancient events (before the beginning of the Christian era) the epicentral locations can only be inferred from archaeological findings or religious accounts in the Bible or Talmudic literature (Ben-Menahem pp. 261-266, 1979)

Most of the seismic events are located along the axis of the Dead Sea Rift. These events, together with microearthquake data, point to a recurrence interval of about 250 years for a $\mathrm{M}_{\mathrm{L}}=$ 6.4 earthquake along the rift (Ben-Menahem, Aboodi, Vered and Kovach, 1977; Ben-Menahem and Aboodi, 1981). Vered (1978) has utilized the geologic record of total fault displacement and the rate of seismic activity to estimate that the maximum expected earthquake along the rift zone would be in the range $M_{L}=7.5-8$.

\section{Seismic Stations and Future Expansion of Jordan Network}

The operating seismograph stations of the Jordan network and the location of stations on the western side of the Dead Sea Rift are shown in Figure 3-1 (Regional Catalog of Earthquakes, 1984). Geographic coordinates and elevations of the seismic stations are listed in Table 3-1. A detailed description of the Jordan seismic network together with the operational procedures can be found in Kovach et al, (1986).

In the near future a number of additional seismic stations will be installed in Jordan to achieve a 32-station network, including a number of three-component stations. This will then provide a network for continuous monitoring of all areas in Jordan. The planned locations of these additional stations are shown in Figure 3-1.

\section{Crustal Structure of Western Jordan}

A number of seismic refraction profiles have been obtained in 1977 and 1984 in the vicinity of the Dead Sea Rift zone (Ginzburg et al, 1979; El-Isa et al, 1986). The location of these profiles are shown on the index map (Figure 4-1).

The north-south profile from Lake Tiberias to the Gulf of Aqaba roughly parallels the axis of the Dead Sea Rift zone. The upper crust, as deduced from an analysis of the seismic refraction and wide angle reflection data, consists of low velocity material $(2.5 \mathrm{~km} / \mathrm{sec})$ overlying a 4.0 $\mathrm{km} / \mathrm{sec}$ layer representing the Paleozoic-Mesozoic sequence of sandstones and limestones. Below the $4.0 \mathrm{~km} / \mathrm{sec}$ material the crust has a velocity of $6 \mathrm{~km} / \mathrm{sec}$ at its upper boundary increasing to $6.7 \mathrm{~km} / \mathrm{sec}$ at its base. The total thickness of the crust is $29-30 \mathrm{~km}$ and the measured upper mantle velocity is $7.8 \mathrm{~km} / \mathrm{sec}$. 
Figure 3-1: Location of Seismograph Stations in Jordan and Adjacent Areas and Future Stations of the Jordan Network.

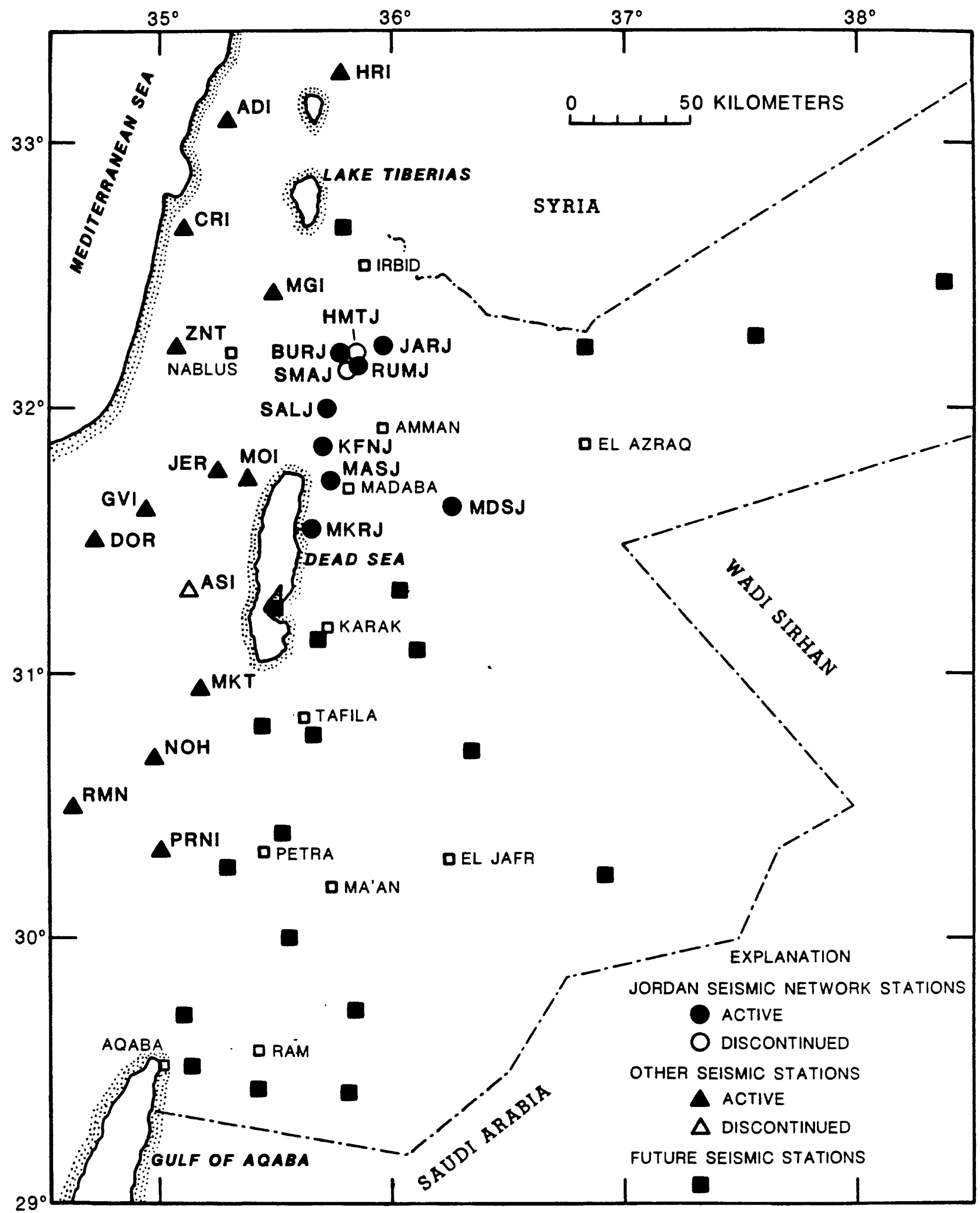


Table 3-1: Seismic Stations in Jordan and Vicinity, Geographical Locations and Elevations.

\begin{tabular}{|c|c|c|c|c|}
\hline STATION NAME & CODE NAME & $\begin{array}{l}\text { LATITUDE } \\
\text { Deg Min }\end{array}$ & $\begin{array}{l}\text { LONGITUDE } \\
\text { Deg Min }\end{array}$ & $\begin{array}{l}\text { ELEVATION } \\
(\mathrm{m})\end{array}$ \\
\hline BURMA & BURJ & $\begin{array}{ll}32 & 12.81\end{array}$ & $35 \quad 45.76$ & 520 \\
\hline JARASH & JARJ & $32 \quad 14.25$ & $\begin{array}{ll}35 & 56.78\end{array}$ & 840 \\
\hline MUDAYSISAT & MDSJ & $\begin{array}{ll}3137.92 \\
\end{array}$ & $\begin{array}{ll}36 & 15.12\end{array}$ & 970 \\
\hline ER RUMMAN & RUMJ & 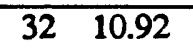 & $35 \quad 49.65$ & 445 \\
\hline SALT & SALJ & 3200.56 & 3541.08 & 780 \\
\hline KAFREIN & KFNJ & 3151.70 & $35 \quad 40.56$ & -90 \\
\hline EL MASLUBIYA & MASJ & $\begin{array}{ll}31 & 43.74\end{array}$ & $35 \quad 43.10$ & 822 \\
\hline MAKAWIR & MKRJ & $\begin{array}{ll}31 & 33.13\end{array}$ & 3538.45 & 815 \\
\hline HAMTA* & HMTJ & $\begin{array}{ll}32 & 13.25\end{array}$ & $\begin{array}{ll}35 & 48.74\end{array}$ & 550 \\
\hline SUMIYA* & SMAJ & $32 \quad 09.30$ & $35 \quad 46.98$ & 565 \\
\hline ADAMIT & ADI & $\begin{array}{ll}33 & 04.90\end{array}$ & $\begin{array}{ll}35 & 14.40\end{array}$ & 500 \\
\hline MT. HERMON & HRI & $33 \quad 16.26$ & $35 \quad 44.76$ & 1060 \\
\hline MT. CARMEL & CRI & $32 \quad 40.92$ & $\begin{array}{ll}35 & 02.70\end{array}$ & 450 \\
\hline MT. GILBOA & MGI & $\begin{array}{ll}32 & 26.82\end{array}$ & $\begin{array}{ll}35 & 26.28\end{array}$ & 300 \\
\hline ZUR NATHAN & $\overline{\mathrm{ZNT}}$ & $\begin{array}{ll}32 & 14.34\end{array}$ & $\begin{array}{ll}35 & 01.92\end{array}$ & 300 \\
\hline MT.MONTAR & MOI & 3144.16 & $35 \quad 21.06$ & 450 \\
\hline BEIT GUVRIN & GVI & $\begin{array}{ll}31 & 37.98\end{array}$ & $\begin{array}{ll}34 & 54.54\end{array}$ & 150 \\
\hline DOROTH & $\overline{\mathrm{DOR}}$ & $\begin{array}{ll}31 & 30.48\end{array}$ & $34 \quad 41.16$ & 130 \\
\hline MT. AMASSA* & ASI & $\begin{array}{ll}31 & 19.80\end{array}$ & $35 \quad 05.70$ & 850 \\
\hline MA'ALE NOAH & $\mathrm{NOH}$ & $30 \quad 41.40$ & $\begin{array}{ll}34 & 57.78\end{array}$ & 600 \\
\hline MT. RAMON & RMN & $\begin{array}{ll}30 & 29.88\end{array}$ & $34 \quad 37.74$ & 1000 \\
\hline PARRAN & PRNI & $30 \quad 20.22$ & $34 \quad 59.88$ & 500 \\
\hline JERUSALEM & JER & $\begin{array}{ll}31 & 45.78\end{array}$ & $35 \quad 13.20$ & 770 \\
\hline BSOR & BSO & $\begin{array}{ll}31 & 16.02\end{array}$ & 3429.10 & 140 \\
\hline MACTESH KATAN & MKT & $\begin{array}{ll}30 & 56.88\end{array}$ & $35 \quad 09.12$ & 540 \\
\hline
\end{tabular}


The east-west profile through Be'er Sheva' reveals a somewhat similar crustal section with the exception of the upper mantle velocity. The sedimentary cover varies in thickness from $4 \mathrm{~km}$ in the east to $6 \mathrm{~km}$ in the west and consists of a low velocity $(2.5 \mathrm{~km} / \mathrm{sec})$ layer, corresponding to Tertiary chalks and marls, which overlies $4.2 \mathrm{~km} / \mathrm{sec}$ material again representing the PaleozoicMesozoic section. The crust has a velocity of $6.0 \mathrm{~km} / \mathrm{sec}$ in the upper part increasing to 6.7 $\mathrm{km} / \mathrm{sec}$ at the crust-mantle boundary. An upper mantle velocity of $8.0 \mathrm{~km} / \mathrm{sec}$ is observed.

In 1984 a number of seismic refraction profiles were obtained in Jordan with observations being made out to distances of approximately $200 \mathrm{~km}$ along four lines (Figure 4-1). The derived crustal section of the north-south profile, which passes, slightly west of Amman, is shown in Figure 4-2. For orientation shot-point 2 is located very close to Amman.

The upper sedimentary layer ranges in velocity from 2.9 to $4.1 \mathrm{~km} / \mathrm{sec}$ and overlies an upper crustal layer to a depth of $18 \mathrm{~km}$ in which the velocity ranges from about $5.8 \mathrm{~km} / \mathrm{sec}$ to 6.35 $\mathrm{km} / \mathrm{sec}$. An intracrustal zone between 18 and $20 \mathrm{~km}$ depth is present with a velocity increasing from 6.35 to $6.65 \mathrm{~km} / \mathrm{sec}$. The lower crust has a constant velocity of $6.65 \mathrm{~km} / \mathrm{sec}$ overlying a 4.5 $\mathrm{km}$ thick transition zone in which the velocity increases from 6.65 to $8.0 \mathrm{~km} / \mathrm{sec}$. A northward dipping crust-mantle boundary is present varying from a depth of about $32 \mathrm{~km}$ beneath shotpoint 3 to $35 \mathrm{~km}$ beneath shot-point 1 . The upper mantle velocity is $8.1 \mathrm{~km} / \mathrm{sec}$.

For purposes of earthquake hypocenter locations in Jordan and vicinity we have adopted a step-wise approximation to the model shown in Figure 4-2. This velocity model is shown by the dashed line in Figure 4-3 and is compared with the old velocity model previously used for epicentral locations in Jordan (Kovach et al, 1986).

\section{Epicentral Locations and Overall Seismicity Pattern}

Our experience in Jordan indicates that accurately locating local earthquakes requires considerable efforts. Accurate station coordinates $(+-0.1 \mathrm{~km}$ if possible) are needed together with an adequate station distribution. A reasonable crustal model, based on controlled explosions is necessary and reliable $P$ and $S$ wave arrival times are essential. It needs to be emphasized that no computer program will give correct answers if the input data contain errors. It should also be pointed out that small travel time residuals and small standard errors do not necessarily guarantee accurate hypocenter solutions.

The program HYPO71 is now in routine use for the determination of hypocenters and earthquake magnitudes in Jordan. 
Figure 4-1: Index Map Showing Location of Seismic Refraction Profiles in the Vicinity of the Dead Sea Rift Zone.

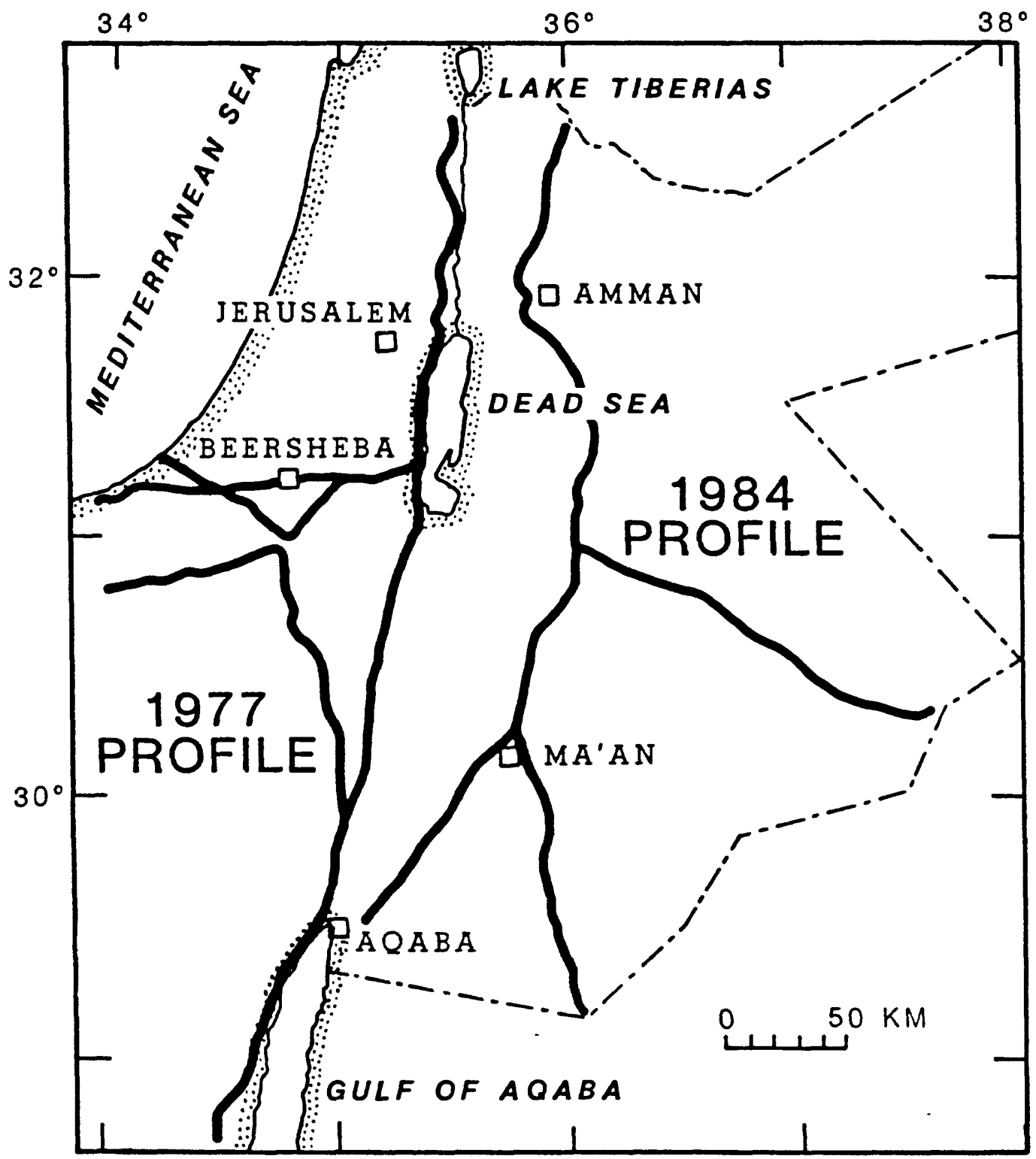


Figure 4-2: Interpreted Crustal Velocity Section for North-South Profile in Jordan. Shot-Point 2 is Near Amman (El-Isa et al, 1986).

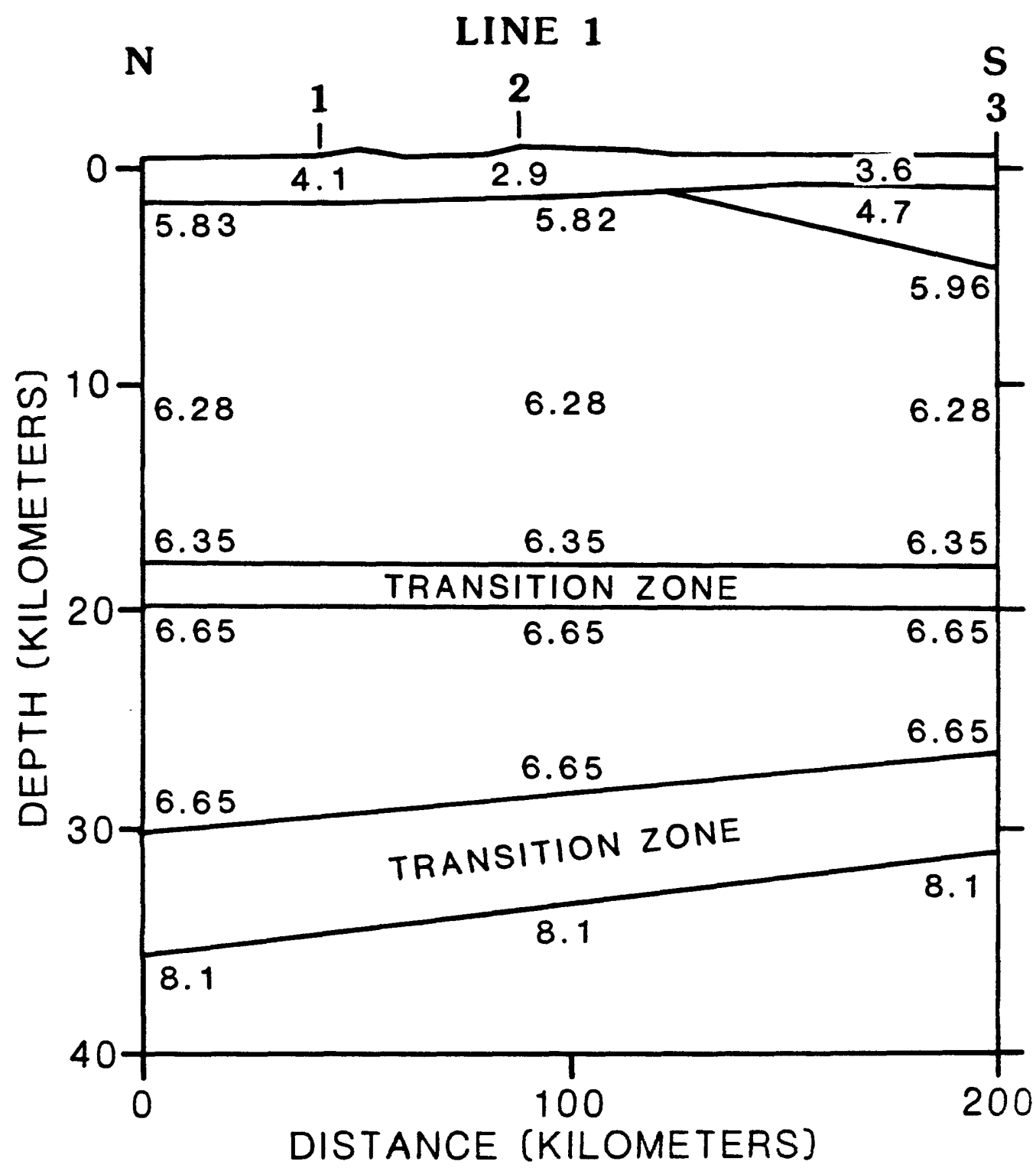


Figure 4-3: Adopted Crustal Velocity Model for Western Jordan

Compared with Velocity Model Previously Used (Kovach et al, 1986).

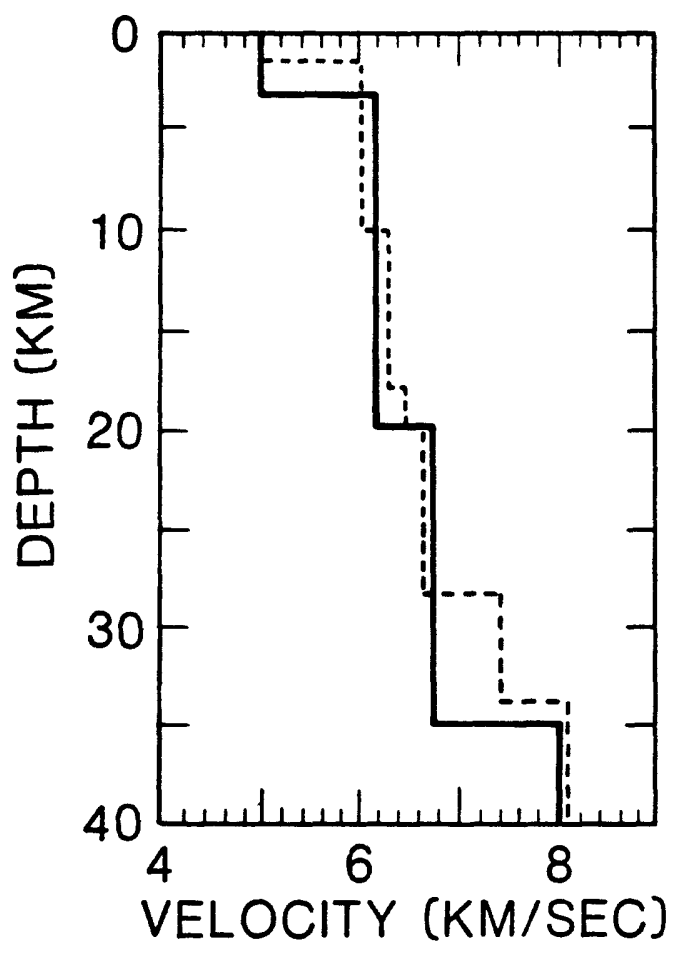


HYPO71 has been the main computer program used by the U.S. Geological Survey for locating local earthquakes and has recently been adapted for use on portable personal computers (Lee and Valdes, 1985) making it possible for field or office use in the rapid analysis of earthquake observations. Previously, a modification of the hypocentral location program LME83 described by Shapira (1983) was utilized.

To test the dependence of the hypocentral locations on the adopted crustal model 7 events were relocated with HYPO71 using the old and new crustal velocity models. In addition, published arrival time data ( $\mathrm{P}$ and S-wave) (Regional Catalog of Earthquakes, ISC, 1984) from seismic stations located on the western side of the Dead Sea Rift were also used to improve the station azimuthal coverage. The results are presented in Table 5-1. It can be seen that the latitude location differences range from 0.2 to $2.0 \mathrm{~km}$ implying that an adequate azimuthal distribution of stations is of paramount importance.

Work is now proceeding on the development of station corrections to improve the location accuracy of events which occur within the Jordan seismic network. The development of station corrections (station delay times to be applied to the observed arrival times) is an evolving trial and error procedure but it appears that the corrections shown in Table 5-2 are the first step.

Table 5-3 shows the comparison of two events located within the Jordan network with and without the above station corrections being applied. It can be seen that the application of station corrections significantly reduces the RMS error of the time residuals.

The local magnitudes $\mathrm{M}_{\mathrm{L}}$ of the seismic events detected by the Jordan seismic network are estimated from the time duration of the seismic signal utilizing the relation

$$
M_{L}=-0.87+2 \log (T)+0.0035 D
$$

where $\mathrm{T}$ is the signal duration in seconds, measured from onset to the point where the signal amplitude is twice the ambient background noise and $\mathrm{D}$ is the epicentral distance in kilometers.

Figure 5-1 is an epicentral map of western Jordan for all of the seismic events located within and near the newtwork for the year 1985. Also shown on the map marked by a small $\mathrm{x}$ are the location of quarries. There are five principal clusters of ever.ts. These clusters are centered: (1) near BURJ and RUMJ (possible construction sites); (2) along the east-west trending fault zone through Zarqa; (3) along the west-southwest trending fault zone through Amman and Na'ur; (4) in the vicinity of MASJ and (5) along the east-west trending fault zone near MKRJ bounded by 
Table 5-1: Comparison of Hypocenter Locations Using Old and New Crustal Velocity Models.

\begin{tabular}{|c|c|c|c|c|c|c|c|c|c|c|}
\hline Model & Date & $\begin{array}{l}\text { Ort } \\
\text { hr }\end{array}$ & gin & $\begin{array}{l}\text { Time } \\
\text { sec }\end{array}$ & $\begin{array}{l}\text { Lat } 1 \\
\text { Deg }\end{array}$ & $\begin{array}{l}\text { Itude } \\
\text { MIn }\end{array}$ & $\begin{array}{l}\text { Long } \\
\text { Deg }\end{array}$ & $\begin{array}{l}\text { Btude } \\
\text { Min }\end{array}$ & Focal Depth & $\begin{array}{l}\text { RMS* } \\
\text { sec }\end{array}$ \\
\hline $\begin{array}{l}\text { Old } \\
\text { New }\end{array}$ & $84-04-05$ & $\begin{array}{l}23 \\
23\end{array}$ & $\begin{array}{l}47 \\
47\end{array}$ & $\begin{array}{l}44.2 \\
44.5\end{array}$ & $\begin{array}{l}32 \\
32\end{array}$ & $\begin{array}{r}9.93 \\
10.27\end{array}$ & $\begin{array}{l}35 \\
35\end{array}$ & $\begin{array}{l}29.76 \\
29.98\end{array}$ & $\begin{array}{l}5.0 \\
7.6\end{array}$ & $\begin{array}{l}0.48 \\
0.62\end{array}$ \\
\hline $\begin{array}{l}\text { Old } \\
\text { New }\end{array}$ & $84-04-26$ & $\begin{array}{l}15 \\
15\end{array}$ & $\begin{array}{l}02 \\
02\end{array}$ & $\begin{array}{l}47.0 \\
47.7\end{array}$ & $\begin{array}{l}32 \\
32\end{array}$ & $\begin{array}{l}47.50 \\
47.34\end{array}$ & $\begin{array}{l}35 \\
35\end{array}$ & $\begin{array}{l}22.58 \\
22.06\end{array}$ & $\begin{array}{l}5.0 \\
3.6\end{array}$ & $\begin{array}{l}0.51 \\
0.39\end{array}$ \\
\hline $\begin{array}{l}\text { Old } \\
\text { New }\end{array}$ & $84-05-30$ & $\begin{array}{l}10 \\
10\end{array}$ & $\begin{array}{l}16 \\
16\end{array}$ & $\begin{array}{l}44.6 \\
45.3\end{array}$ & $\begin{array}{l}32 \\
32\end{array}$ & $\begin{array}{l}17.39 \\
17.07\end{array}$ & $\begin{array}{l}35 \\
35\end{array}$ & $\begin{array}{l}21.44 \\
21.54\end{array}$ & $\begin{array}{l}7.6 \\
5.0\end{array}$ & $\begin{array}{l}0.36 \\
0.28\end{array}$ \\
\hline $\begin{array}{l}\text { O1d } \\
\text { New }\end{array}$ & $84-08-02$ & $\begin{array}{l}11 \\
11\end{array}$ & $\begin{array}{l}04 \\
04\end{array}$ & $\begin{array}{l}6.7 \\
7.2\end{array}$ & $\begin{array}{l}31 \\
31\end{array}$ & $\begin{array}{l}44.28 \\
45.34\end{array}$ & $\begin{array}{l}35 \\
35\end{array}$ & $\begin{array}{l}30.68 \\
.30 .84\end{array}$ & $\begin{array}{l}13.5 \\
12.0\end{array}$ & $\begin{array}{l}0.47 \\
0.43\end{array}$ \\
\hline $\begin{array}{l}\text { 01d } \\
\text { New }\end{array}$ & $84-08-02$ & $\begin{array}{l}14 \\
14\end{array}$ & $\begin{array}{l}01 \\
01\end{array}$ & $\begin{array}{l}27.0 \\
27.5\end{array}$ & $\begin{array}{l}31 \\
31\end{array}$ & $\begin{array}{l}45.58 \\
45.08\end{array}$ & $\begin{array}{l}35 \\
35\end{array}$ & $\begin{array}{l}30.57 \\
31.42\end{array}$ & $\begin{array}{r}10.6 \\
5.0\end{array}$ & $\begin{array}{l}0.30 \\
0.24\end{array}$ \\
\hline $\begin{array}{l}\text { 01d } \\
\text { New }\end{array}$ & $84-08-10$ & $\begin{array}{l}02 \\
02\end{array}$ & $\begin{array}{l}50 \\
50\end{array}$ & $\begin{array}{l}46.6 \\
46.8\end{array}$ & $\begin{array}{l}32 \\
32\end{array}$ & $\begin{array}{l}4.86 \\
5.40\end{array}$ & $\begin{array}{l}36 \\
36\end{array}$ & $\begin{array}{l}13.25 \\
14.35\end{array}$ & $\begin{array}{l}11.7 \\
12.7\end{array}$ & $\begin{array}{l}0.26 \\
0.26\end{array}$ \\
\hline $\begin{array}{l}\text { Old } \\
\text { New }\end{array}$ & $84-08-24$ & $\begin{array}{l}06 \\
06\end{array}$ & $\begin{array}{l}02 \\
02\end{array}$ & $\begin{array}{l}26.1 \\
26.6\end{array}$ & $\begin{array}{l}32 \\
32\end{array}$ & $\begin{array}{l}39.35 \\
39.32\end{array}$ & $\begin{array}{l}35 \\
35\end{array}$ & $\begin{array}{l}14.94 \\
13.88\end{array}$ & $\begin{array}{r}9.8 \\
11.4\end{array}$ & $\begin{array}{l}0.84 \\
0.97\end{array}$ \\
\hline
\end{tabular}

*see Table 5-3 
Table 5-2: Trial Station Delays for Some Jordan Seismic Stations.

\begin{tabular}{|c|c|}
\hline Station & Delay (sec) \\
\hline BURJ & -0.10 \\
\hline JARJ & -0.10 \\
\hline MDSJ & 0.14 \\
\hline SALJ & 0.10 \\
\hline MASJ & 0.14 \\
\hline MKRJ & 0.16 \\
\hline
\end{tabular}


Table 5-3: Comparison of Hypocenter Locations Using HYPO71 With and Without Station Corrections and LME83 Without Station Corrections.

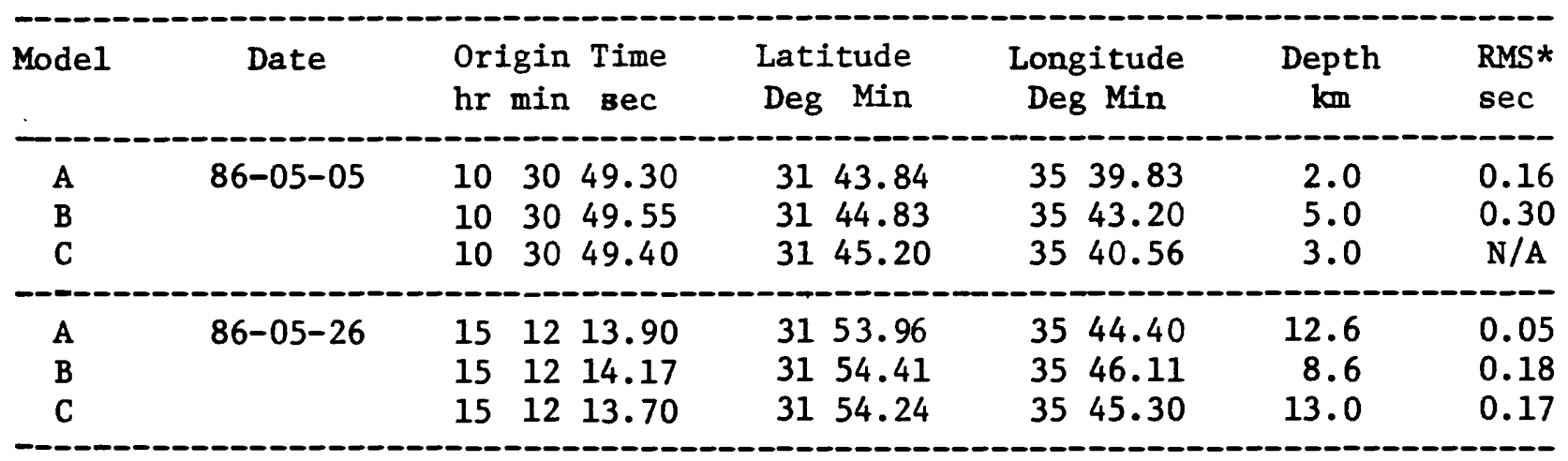

$A=$ HYP071 with station corrections.

B $=$ HYP071 without station corrections.

$C=$ LME83 without station corrections.

RMS* is here defined as the root-mean-square error of the time residuals except $N$, the number of observations, has been replaced by $\mathrm{N}-4$ in accordance with recent modifications made to the program HYP071 (Lee and Valdes, 1985). RMS $=\left[\sum_{i} R_{i}^{2} /(N-4)\right]^{\frac{1}{2}}$, where $R_{i}$ is the time residual 
Figure 5-1: Epicentral Map of Western Jordan for the Year 1985.

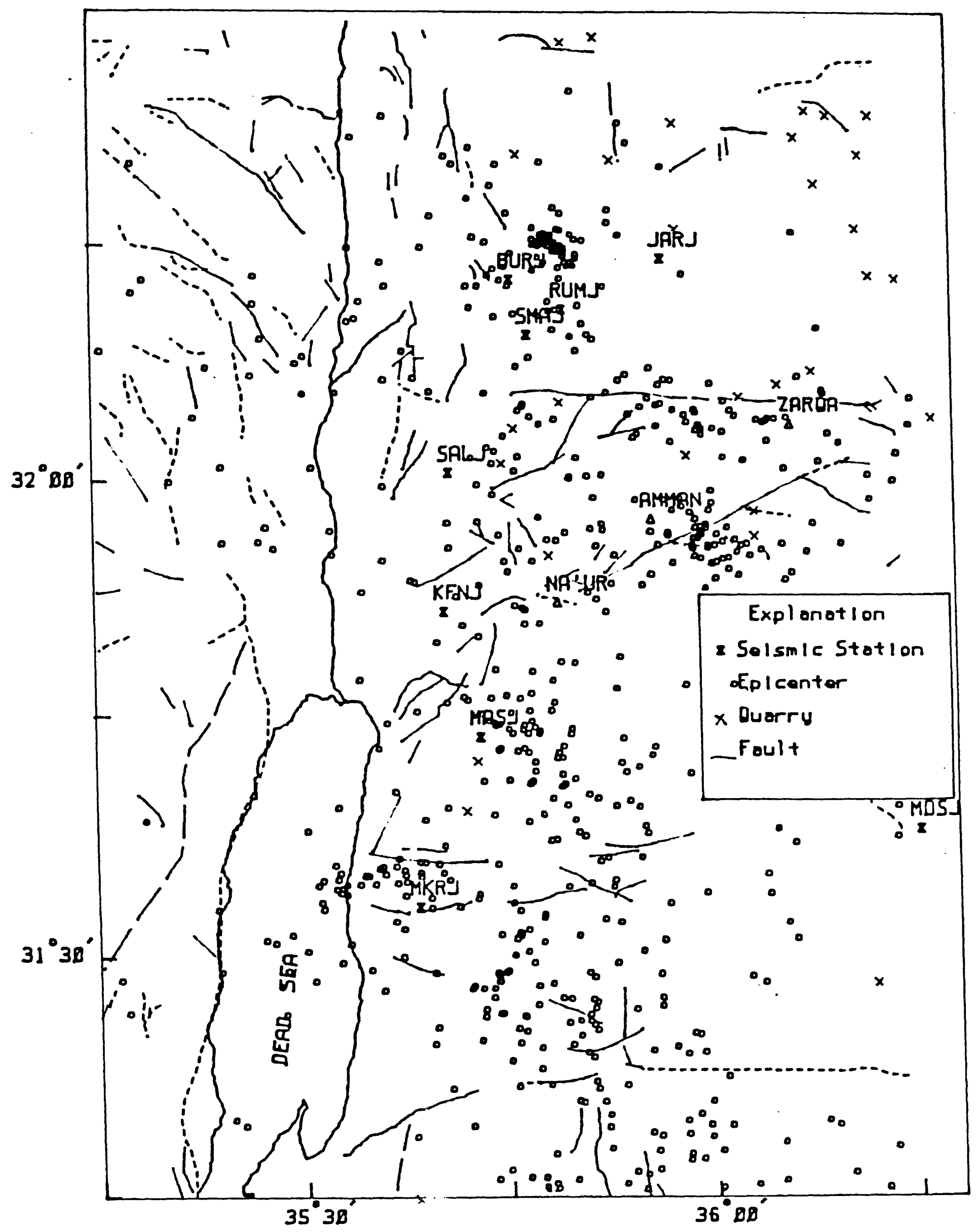


the faults between which are the Zerqa main geothermal hot springs. In addition, there is a diffuse zone of activity south of latitude $31^{\circ} 30^{\prime} \mathrm{N}$ but these events should be interpreted with caution because of their location with respect to the seismic network.

With few exceptions, the epicenter locations show a strong correlation with mapped fault zones or their logical extensions when the approximately $6 \mathrm{~km}$ diameter circle of location uncertainty is taken into consideration. The distributed pattern of seismicity suggests that in this region, shear due to the differential motion of the Arabian plate relative to Sinai is accommodated in part on easterly and northerly trending faults in a broad zone rather than just along the Dead Sea fault zone itself. Geothermal activity associated with the cooling of the young basalts in the Zerqa Ma'in and Wadi Mawjib areas may constitute another source of earthquake activity. The cluster of earthquakes observed south and east of station Maslubiya has no surface expression in either mapped faults or young volcanism.

\section{Tectonic Framework and Focal Plane Solutions}

Before discussing a few seismic focal mechanisms it is useful to review some aspects of the tectonic evolution and setting of the Dead Sea Rift. The structure of the Dead Sea Rift is primarily the result of left lateral strike-slip motion mixed with uplifting along its sides. The net result is to produce rift faulting which traverses a topographically and structurally uplifted region. In a plan view the rift zone changes direction so that blocks along its two sides cannot fit together once strike-slip motion has occurred. As a result along some sections of the rift zone gaps are opened producing structural and topographic depressions, the so-called rift valleys. Along other segments local compression arises (Figure 6-1). Topographically, the boundaries of the gaps or depressions produced along the rift are controlled by dip-slip faulting. However, much of the present strike-slip motion takes place on en-echelon faults which strike at an angle to the main overall trend of the rift. As a consequence rhomb shaped grabens or pull apart basins are produced together with intervening segments of structural and topographic saddles (Figure 6-2). The slip along the Dead Sea Rift Zone is believed to have taken place in several stages inasmuch as in the southern part of the rift the pull-apart basins are only about $40-50 \mathrm{~km}$ in length whereas a total strike-slip movement of about $105 \mathrm{~km}$ has occurred. The slip which produced these basins cannot be greater than their length so the additional movement necessary to produce the $100 \mathrm{~km}$ or so of total left-lateral offset must have occurred at an earlier time, probably in a direction more aligned with the overall trend of the rift (Figure 6-3).

Focal mechanisms for several earthquakes in the vicinity of the Dead Sea Rift Zone were determined using the grid searching program FPFIT (Reasenberg and Oppenheimer, 1985). First 
Figure 6-1: A Model for the Overall Structure of the Dead Sea Rift (Freund, 1965).

(a)

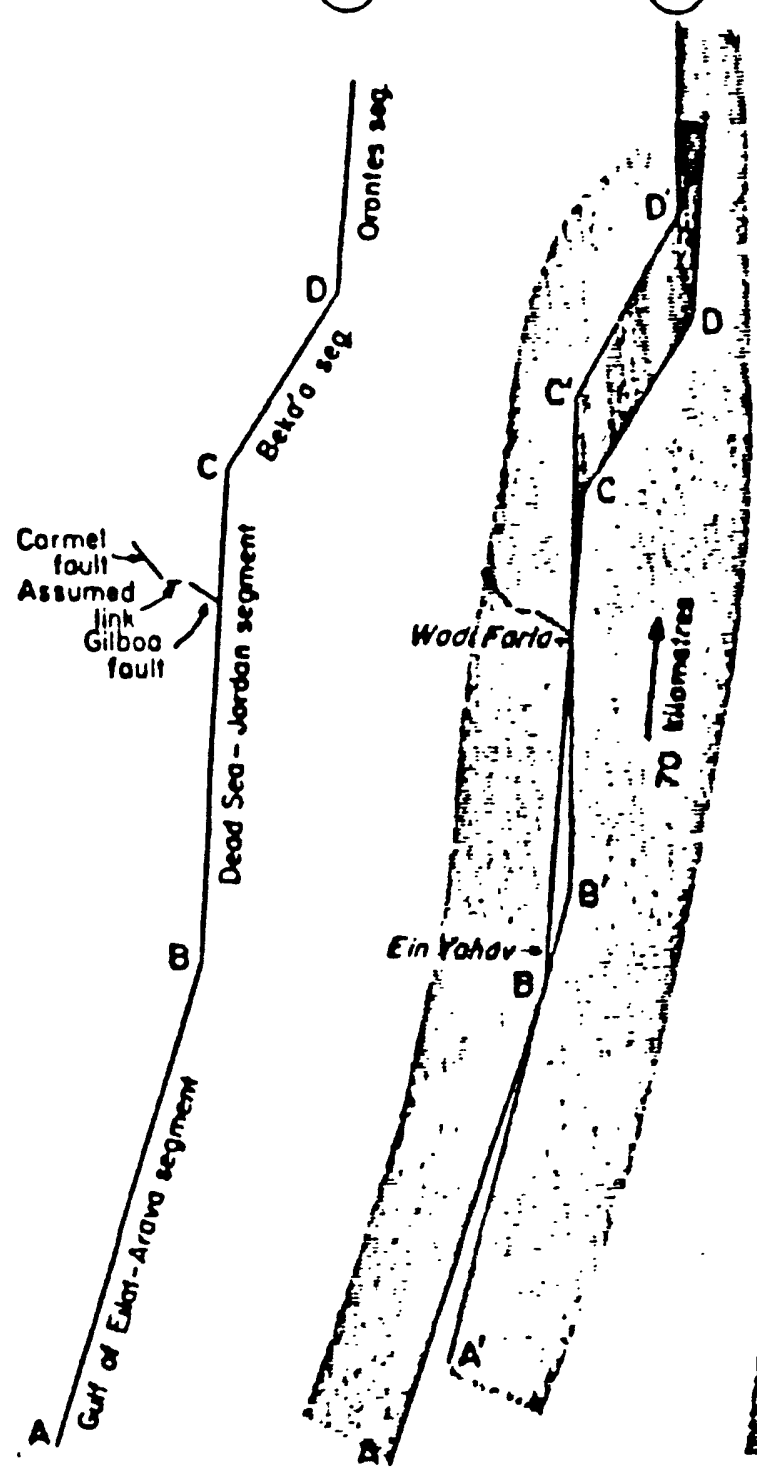

(c)

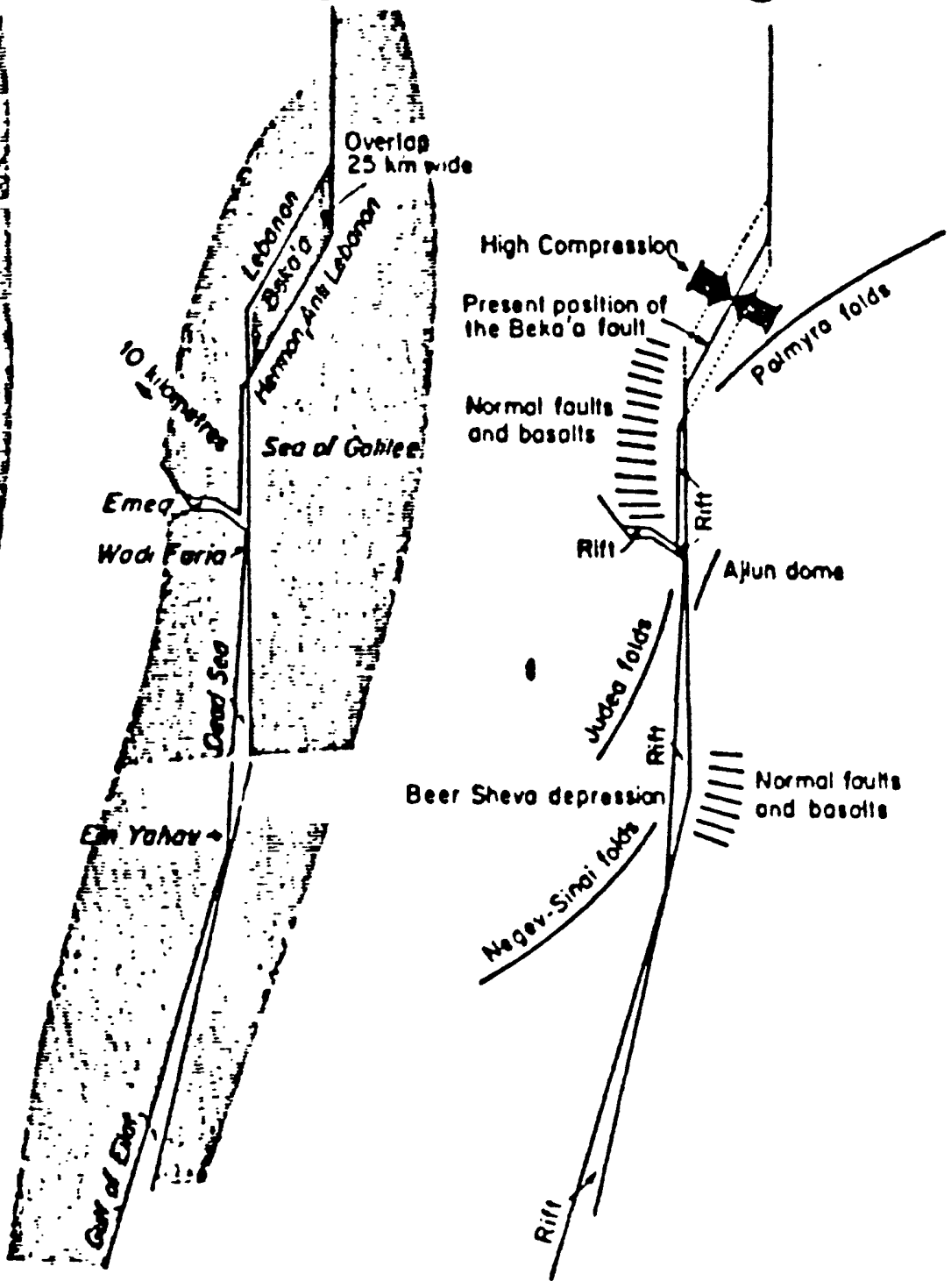


Figure 6-2: Model for the Formation of Rhomb Grabens or Pull-Apart Basins Along the Northern Segment of the Dead Sea Rift (Freund and Garfunkel, 1976).

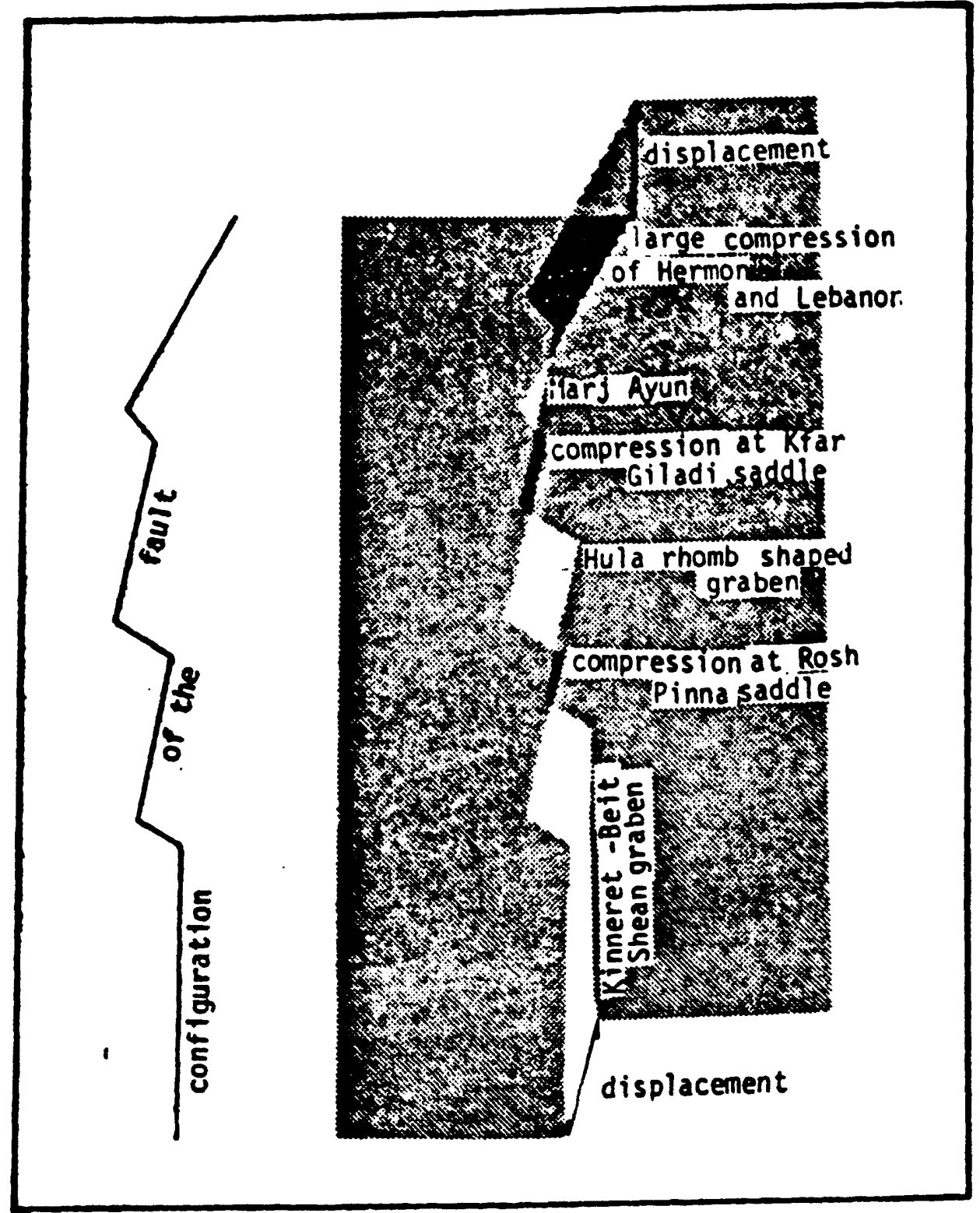


Figure 6-3: Cartoon showing the Presumed Development of the Dead Sea Basin

(Freund and Garfunkel, 1976).

\section{1. fault trace}

2. Pre Miocene

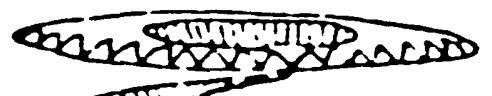

$62 \mathrm{~km}$ movement

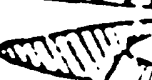

$3 \% 17$

Fin!lin!

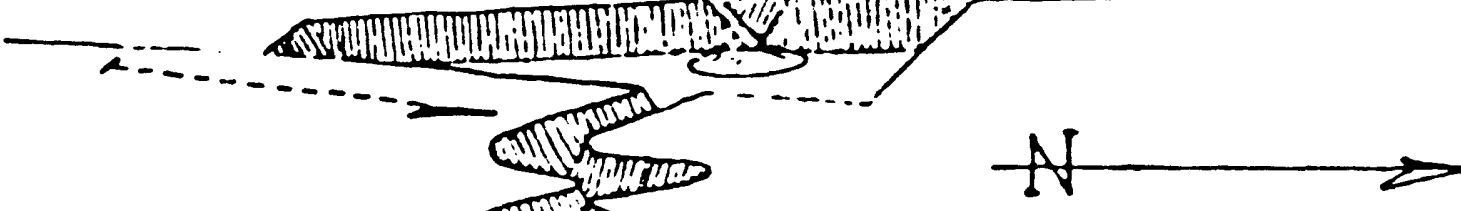

3. Late Miocene depression filled by Hazeva $\mathrm{Fm}$.
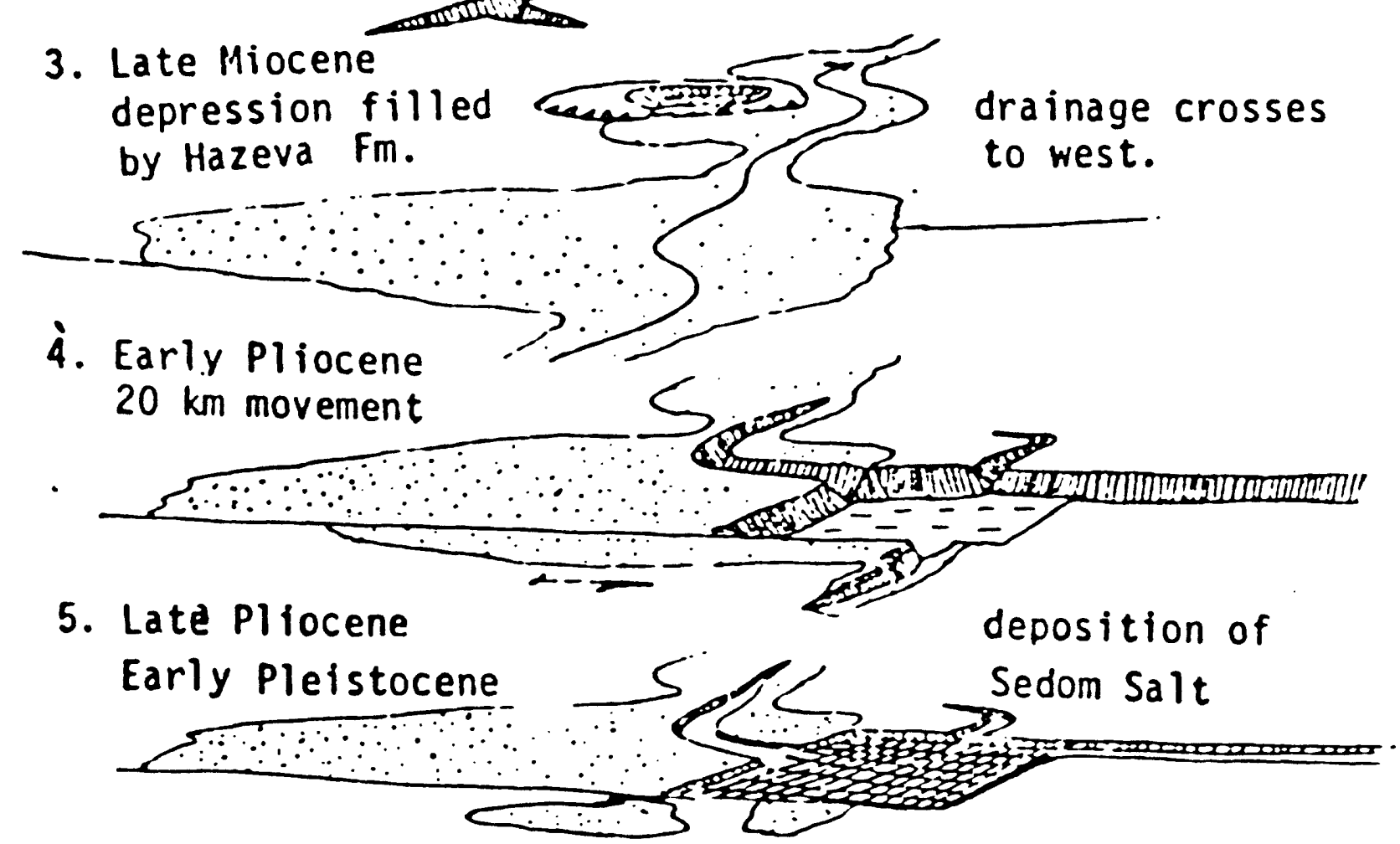

6. Recent

$20 \mathrm{~km}$ movement

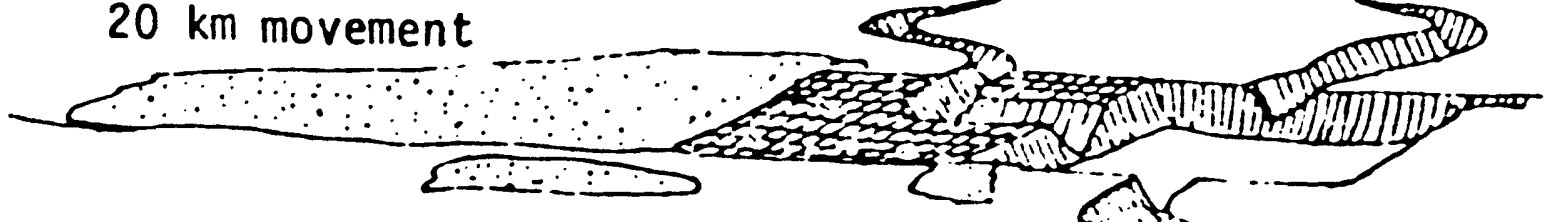

- 3232 232

leads to the present-day northern depression of the Dead'Sea. 
Figure 6-4: Focal Plane Solutions for Some Earthquakes Near the Dead Sea Rift Zone.

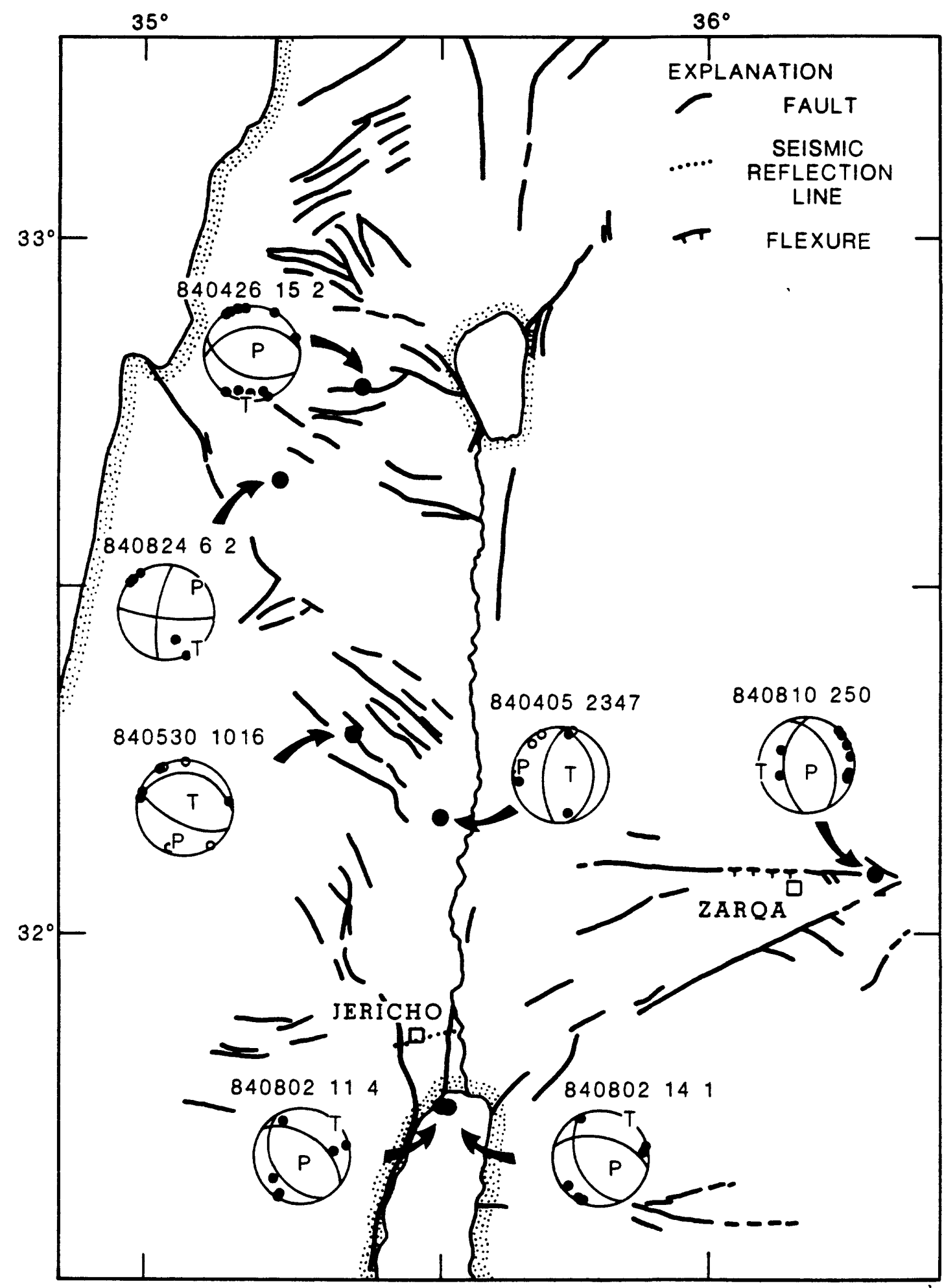


motion polarities from stations on the west side of the rift were kindly provided by Shapira (personal communication). A few general observations can be made concerning the focal plane solutions shown in 6-4.

The two events of August 2,1984, located in the northern end of the Dead Sea exhibit normal faulting with the axis of tension (the axis of minimum compressive stress) oriented SW-NE. A normal faulting mechanism is compatible with the concept of a rhomb graben or pull-apart structure for the Dead Sea basin in which the northern part of the basin is bounded by a northwesterly trending normal fault.

Further north, the events of April 5 and May 30, 1984, possess thrust fault mechanisms. As mentioned earlier local compression is to be expected along certain segments of the rift zone, particularly in the regions between the northerly trending pull-apart basins.

Viewed collectively, the focal plane solutions exhibit a diversity of faulting mechanisms which provide some insight into the tectonic framework of the Dead Sea Rift Zone. However, it should be borne in mind that individual earthquake mechanism solutions do not necessarily always reflect the actual tectonic stress field.

\section{Acknowledgments}

The operation of the microseismic network in Jordan is the result of the enthusiastic support of the officials and staff of the Natural Resources of the Hashemite Kingdom of Jordan and the United States Agency for International Development. 


\section{References}

1. Alsinawi, S., and Ghalib, H.A.A., Historical Seismicity of Iraq, Bull. Seismological Soc. Amer., 65, 541-547, (1975).

2. Ambrayseys, N.N., On the Seismicity of Southwest Asia, Data from a XV Century Arabic Manuscript, Revue Pour L'Etude des Calamites, (No. 37), Geneva, (1961).

3. Ambrayseys, N.N., A Note on the Chronology of Willis' list of Earthquakes in Palestine and Syria, Bull. Seismological Soc. Amer., 52, 77-80, (1962).

4. Ambrayseys, N.N., and Melville, C.P., A History of Persian Earthquakes, Cambridge University Press, London, 219pp., (1982).

5. Amiran, D.H.K., A Revised Earthquake Catalogue of Palestine, Israel Exploration Journal, 1, 223-246, (1950-51).

6. Amiran, D.H.K., A Revised Earthquake Catalogue of Palestine (Part 2), Israel Exploration Journal, 2, 48-65, (1951).

7. Arieh, E., Seismicity of Israel and Adjacent Areas, Geol. Surv. Israel Bull., 43, $1-14,(1967)$.

8. Arieh, E., A Note on the Seismicity of Israel (1900-1982), Bull. Seismological Soc. Amer., 75, 881-887, (1985).

9. Arieh, E., Peled, U., Kafri, U., and Shaal, B., The Jordan Valley Earthquake of September 2, 1973, Israel Jour. of Earth Sciences, 26, 112-118, (1977).

10. Arieh, E., Rotstein, Y., and Peled, U., The Dead Sea Earthquake of 23 April 1979, Bull. Seismological Soc. Amer., 72, 1627-1634, (1982).

11. Avi-Yonah, M., Editor, Encyclopedia of Archaeological Excavations in the Holy Land, London, (1975/76).

12. Ben-Menahem, A., and Aboodi, E., Micro-and Macroseismicity of the Dead Sea Rift and Off-Coast Eastem Mediterranean, Tectonophysics, 80, 199-233, (1981).

13. Ben-Menahem, A., Earthquake Catalog for the Middle East (92 B.C.-1980 A.D.), Bull. Geof. Teor. Appl., 84, 245-310, (1979).

14. Ben-Menahem, A., Aboodi, E., Vered, M. and Kovach, R.L., Rate of Seismicity of the Dead-Sea Region over the Past 4000 Years, Phys. Earth Planet. Inter., 14, 17-27, (1977).

15. Blanckenhom, M., Uber die letzten Erdbeben in Palastina und die Erforschung etwaiger kunftiger, Zeitschrift des Deutschen Palastina-Vereins, 28, 206-218, (1905).

16. Blanckenhom, M., Erdbeben in Palastina, Zeitchrift des Deutschen Palastina-Vereins, 48, p.166, (1925).

17. Blanckenhom, M., Das Erdbeben in Juli 1927 in Palastina, Zeitschrift des Deutschen Palastina-Vereins, 50, 288-296, (1927).

18. Blanckenhom, M., Neue Erdbeben in Jerusalem, Zeitschrift des Deutschen 
Palastina-Vereins, 51, 123-125, (1928).

19. El-Isa, Z.H., and Mustafa, H., Earthquake Deformations in the Lisan Deposits and Seismotectonic Implications, Geophys. J.R. Astr. Soc., 86, 413-424, (1986).

20. El-Isa, Z.H., Merghelani, H.M. and Bazzari, M.A., The Gulf of Aqaba Earthquake Swarm of of 1983 January-April, Geophys. J. R. Astr. Soc., 78, 711-722, (1984).

21. El-Isa, Z.H., Mechie, J., Prodehl, C., Makris, J., and Rihm, R., A Crustal Structure Study of Jordan Derived from Seismic Refraction Data, in Spannung und Spannungsumwandlung in der Lithosphäre, Sonderforschungsbereich 108, Universität Karlsruhe, 1009-1047, (1986).

22. El-Isa, Z.H., Mechie, J., and Prodehl, C., S-Wave and Poisson's Ratio Structure Beneath Central Jordan, in Spannung und Spannungumwandlung in der Lithosphäre, Sonderforschungsbereich 108, Universität Karlsruhe, 1049-1063, (1986).

23. Freund, R., A Model for the Structural Development of Israel and Adjacent Areas Since Upper Cretaceous Times, Geological Magazine, 102, 189-205, (1965).

24. Freund, R., and Garfunkel, Z., Guidebook to Excursion along the Dead Sea Rift, Dept. of Geology, Hebrew University, 46pp., (1976).

25. Ginzburg, A., Makris, J., Fuchs, K., Prodehl, C., Kaminski, W., and Amitai, U., A Seismic Study of the Crust and Upper Mantle of the Jordan-Dead Sea Rift and Their Transition Toward the Mediterranean Sea, Jour. of Geophysical Res., 84, 1569-1582, (1979).

26. Kashai, E.L., and Croher, P.F., The Evolution of the Dead Sea-Jordan Rift System as Evidenced by New Subsurface Data, Tectonophysics, in press, (1986).

27. Kovach, R.L., Andreasen, G., Gettings, M., and Healy, J., The Jordan Seismological Observatory, U.S. Geological Survey Open File Report 86-384, 18pp., (1986).

28. Lee, W.H.K., and Valdes, C.M., HYPO71PC: A Personal Computer Version of the HYPO71 Earthquake Location Program, U.S. Geological Survey Open File Report 85-749, 43pp., (1985).

29. Perrey, A., Memoire sur les Tremblement de Terre Resentis Dans La Peninsule Turco-Hellenique et en Syrie, Memoires Couronnes et Memoires de Savants Etrangers, Academie Royale de Belgique, Bruxelles, 23, 1-73, (1849).

30. Poirier, J.P. and M. Taher, Historical Seismicity in the Near and Middle East, North Africa, and Spain from Arabic Documents (VIIth to XVIIIth Century), Bull. Seismological Soc. Amer., 70, 2185-2201, (1980).

31. Poirier, J.P., and Romanowicz, B. and Taher, M., Large Historical Earthquakes and Seismic Risk in Northwest Syria, Nature, 285, 217-220, (1980).

32. Reasenberg, P., and Oppenheimer, D., FPFIT, FPPLOT and FPPAGE: Fortran Computer Programs for Calculating and Displaying Earthquake Fault-Plane Solutions, U.S. Geological Survey Open File Report 85-739, 46pp., (1985).

33. Regional Catalogue of Earthquakes, International Seismological Centre, Newbury, United Kingdom, (1979-84). 
34. Shapira, A., A Guide for Using LME 83, IPRG Report Z1/567/79(16), 1-13, 2 appendices, (1983).

35. Sieberg, A., Handbuch der Geophysik, Band IV, Erdbebengeographie, Borntraeger, Berlin, 527-1005, (1932a).

36. Sieberg, A., Untersuchungen uber Erdbeben und Bruchschollenbau im ostlichen Mittelmeergebiet, Denkschriften der Medizinisch Naturwissenschaftlichen Gesellschaft zu Jena, 18, 159-273, (1932b).

37. Sprenger, A., As-Soyuti's Work on Earthquakes, Jour. Asiatic Society Bengal, 12 741-749, (1843).

38. Tristram, H.B., The Land of Israel, Society for Promoting Christian Knowledge, London, 651pp., (1865).

39. Tristram, H.B., The Land of Moab: Travels and Discoveries on the East Side of the Dead Sea and the Jordan, John Murray, London, 416pp., (1874).

40. Vered, M., The Probable Maximum Earthquake Magnitude Associated with the Jordan Rift, Israel Jour. of Earth Sciences, 27, 82-84, (1978).

41. Vered, M., and Striem, H., A Macroseismic Study and the Implications of Structural Damage of Two Recent Major Earthquakes in the Jordan Rift, Bull. Seismological Soc. Amer. 67, 1607-1613, (1977).

42. Watson, C.M., The Stoppage of the River Jordan in A.D. 1267, Quarterly Palestine Exploration Fund, 253-261, (1895).

43. Willis, B., Earthquakes in the Holy Land, Bull. Seismological Soc. Amer., 18, 73-103, (Amendment in Science, April 7, 1933, p.351), (1928). 